УДК 159.923

DOI https://doi.org/10.26661/2310-4368/2021-1-5

\title{
ОРГАНІЗАЦЙНО-ПСИХОЛОГІЧНІ ХАРАКТЕРИСТИКИ РОЗВИТКУ ІННОВАЦІЙНИХ СТИЛІВ УПРАВЛІННЯ В МЕНЕДЖЕРІВ ОСВІТНІХ ОРГАНІЗАЦІЙ
}

\author{
Клочко А. О. \\ кандидат педагогічних наук, доиент, \\ науковий кореспондент лабораторії організаційної та соціальної психології \\ Інститут психології імені Г. С. Костюка Національної академії педагогічних наук Украӥни \\ вул. Паньківська, 2, Київ, Україна \\ orcid.org/0000-0001-6631-2638 \\ klochko_alla@ukr.net
}

\begin{abstract}
Ключові слова: освітні організації, менеджери освітніх організачій, інновачійні стилі управління, організаційнопсихологічні характеристики.
\end{abstract}

Ефективність функціонування освітніх організацій залежить від обраного менеджерами освіти стилю управління. У статті представлено модель організаційно-психологічних характеристик розвитку інноваційних стилів управління в менеджерів освітніх організацій. Виділено три групи організаційно-психологічних характеристик, що впливають на розвиток інноваційних стилів управління в менеджерів освіти. До кожної з груп ввійшли характеристики, які стосуються психологічних характеристик менеджерів та освітніх організацій, і характеристики, які пов'язані 3 організаційно-функціональними, характеристиками організації та організаційно-професійними й соціально-демографічними характеристиками менеджерів освіти. Першу групу становлять організаційно-психологічні характеристики, які зумовлені особливостями розвитку освітніх організацій: психологічні (рівень організаційного розвитку; особливості педагогічного колективу; креативний потенціал) та організаційно-професійні характеристики освітніх організацій. Другу групу утворили організаційно-психологічні характеристики, які зумовлені особливостями діяльності та поведінки менеджерів освітніх організацій (психологічні, організаційно-функціональні та соціально-демографічні). До психологічних характеристик групи віднесено: особистісні характеристики менеджерів освіти (екстраверсія; прив'язаність; самоконтроль; емоційна стійкість; експресивність); здатність менеджерів до саморозвитку; в) креативний потенціал менеджерів освіти («моя особистість»; «мій підхід до розв’язання проблем»). Третя група організаційно-психологічних характеристик розвитку інноваційних стилів управління зумовлена особливостями взаємодії менеджерів з освітніми організаціями (задоволеність роботою, показники суб'єктивного благополуччя, відданість організації). Вивчення психологічних характеристик розвитку інноваційних стилів управління може бути покладено в основу як емпіричних досліджень, спрямованих на вивчення психологічних чинників розвитку й особливостей діяльності освітніх організацій, так і в основу тренінгових програм для психологічної підготовки менеджерів освітніх організацій. 


\title{
ORGANIZATIONAL AND PSYCHOLOGICAL CHARACTERISTICS \\ OF DEVELOPMENT OF INNOVATIVE MANAGEMENT STYLES IN MANAGERS OF EDUCATIONAL ORGANIZATIONS
}

\author{
Klochko A. O. \\ Candidate of Pedagogical Sciences, Associate Professor, \\ Scientific Correspondent at the Laboratory of Organizational and Social Psychology \\ G. S. Kostiyk Institute of Psychology of National Academy of Pedagogical Sciences of Ukraine \\ Pankivska str., 2, Kyiv, Ukraine \\ orcid.org/0000-0001-6631-2638 \\ klochko_alla@ukr.net
}

Key words: educational organizations, managers of educational organizations, innovative management styles, organizational and psychological characteristics.

\begin{abstract}
The effectiveness of the functioning of educational organizations depends on the chosen management style managers. The article presents a model of organizational and psychological characteristics of the development of innovative management styles in managers of educational organizations. Three groups of organizational and psychological characteristics are highlighted, which affect the development of innovative management styles in education managers. Each group included characteristics related to the psychological characteristics of managers and educational organizations and characteristics related to organizational and functional, organizational characteristics and organizational-professional and socio-demographic characteristics of educational managers. The first group consists of organizational and psychological characteristics, which are due to the peculiarities of the development of educational organizations: psychological (level of organizational development; features of the teaching staff; creative potential) and organizational and professional characteristics of educational organizations. The second group was formed by organizational and psychological characteristics, which are due to the peculiarities of the activities and behavior of managers of educational organizations (psychological, organizational, functional and sociodemographic). The psychological characteristics of the group include: personal characteristics of education managers (extraversion; attachment; self-control; emotional stability; expressiveness); the ability of managers to self-development; c) creative potential of education managers ("my personality"; "my approach to solving problems"). The third group of organizational and psychological characteristics of the development of innovative management styles, due to the peculiarities of the interaction of managers with educational organizations (job satisfaction, indicators of subjective well-being, commitment to the organization). The study of psychological characteristics of the development of innovative management styles can be the basis of both empirical research aimed at studying the psychological factors of development and features of educational organizations, and the basis of training programs for psychological training of managers of educational organizations.
\end{abstract}

Постановка проблеми. Економічні та соціальні реформи в Україні формують нові підходи до процесу управління. Ефективність функціонування освітніх організацій залежить від вправної управлінської діяльності, тому значення керівництва в освітніх організаціях є актуальним питанням сьогодення. Вміння керівника створити сприятливий соціально-психологічний клімат в колективі, зацікавити роботою працівників, застосувати певні мотиваційні та управлінські методи, виявити свої лідерські здібності, вміння спілкуватися та вирішувати конфліктні ситуації - все це залежить від обраного інноваційного стилю управління і впливає на результативність діяльності освітньої організації. Тому виникає необхідність дослідження організаційно-психологічних характеристик, що впливають на розвиток інноваційних стилів управління менеджерів освітніх організацій.

Психологічні особливості стилів управління керівників, зокрема, в освітніх організаціях, 
розглянуто у працях М. Альберт, М. Мескон, Ф. Хедоурі [13], Б. Андрушків [1], К. Боумен [3], А. Журавльов [4], Л. Коломинського [11], Л. Орбан-Лембрик [14].

Психологічний аспект, зокрема, фактори, які впливають на стиль, що обирає керівник для реалізації управлінської діяльності, описували у своїх працях Л. Карамушка [8], В. Лозниця [12], Р. Шакуров [17], Г. Шредер [18].

У попередніх наших публікаціях [9; 10] було визначено інноваційні стилі управління за емоційним інтелектом, за ставленням до змін та за формуванням взаємостосунків із педагогічним колективом менеджерів освітніх організацій.

Водночас теоретичний аналіз наукової літератури показує, що, незважаючи на численні акценти щодо важливості психологічної складової розвитку стилів управління, фактично відсутні цілісні концептуальні психологічні дослідження 3 цього напрямку.

Ще менш дослідженим аспектом $є$ проблема розвитку інноваційних стилів управління менеджерів освітніх організацій. Як свідчить аналіз наукової літератури, безпосередньо проблема психології розвитку інноваційних стилів управління менеджерів освіти не розроблялась належним чином.

Відповідно, мета дослідження полягає в розкритті організаційно-психологічних характеристик розвитку інноваційних стилів управління у менеджерів освітніх організацій.

Виклад основного матеріалу дослідження. Теоретичний аналіз проблеми дозволив розро- бити модель організаційно-психологічних характеристик розвитку інноваційних стилів управління у менеджерів освітніх організацій (рис. 1).

Ми виділили три групи організаційно-психологічних характеристик, які впливають на розвиток інноваційних стилів управління у менеджерів освітніх організацій, а саме: 1) організаційно-психологічні характеристики організації (зумовлені особливостями розвитку освітніх організацій); 2) організаційно-психологічні характеристики особистості (зумовлені особливостями діяльності та поведінки менеджерів освітніх організацій); 3) психологічні характеристики взаємодії особистості та організації (зумовлені особливостями взаємодії менеджерів з освітніми організаціями).

Далі у процесі поглибленого аналізу характеристик та з урахуванням розробок Л. Карамушки [7], було здійснено розподіл організаційно-характеристик кожної з груп. Проаналізуємо зміст організаційно-психологічних характеристик кожної групи характеристик.

До першої групи організаційно-психологічних характеристик, які зумовлені особливостями розвитку освітніх організацій, нами віднесено характеристики, які стосуються психологічних та організаційно-професійних характеристик освітніх організацій.

Серед психологічних характеристик освітніх організацій виділено ті, які зумовлені особливостями їх розвитку: рівень організаційного розвитку (організаційна зрілість; проблемність організаційного розвитку); особливості педагогічного колективу (підготовленість до діяльності;

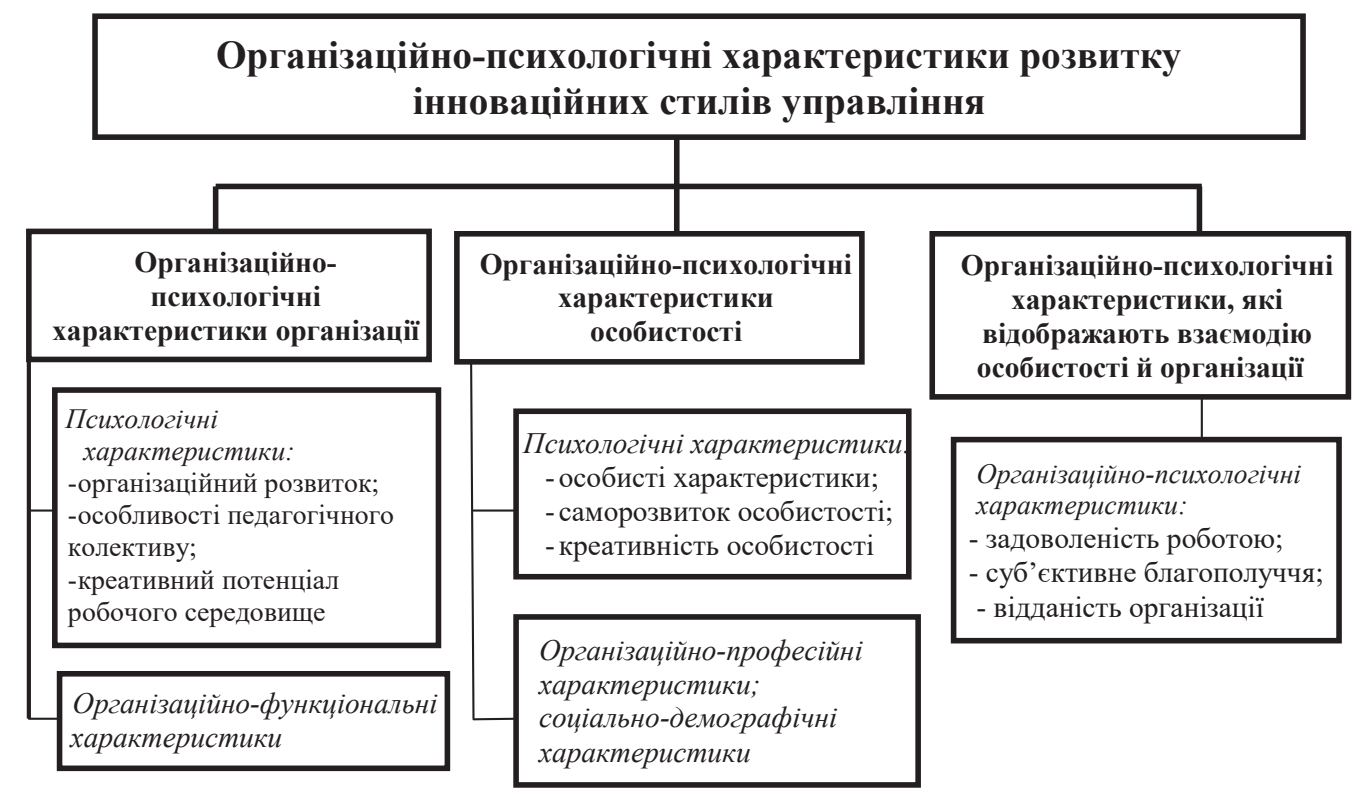

Рис. 1. Модель організаційно-психологічних характеристик розвитку інноваційних стилів управління у менеджерів освітніх організацій 
направленість; організованість; активність; згуртованість; інтегративність; референтність); креативний потенціал освітніх організацій (робоче середовище).

До організаційно-функціональних характеристик освітніх організацій віднесено: тип освітньої організації; місце розташування; термін існування; кількість працівників в освітній організації; кількість учнів; статус освітньої організації в освітній системі; статус інноваційності освітньої організації в освітній системі тип освітньої організації за специфікою функціонування; місце розташування освітньої організації; термін існування освітньої організації; кількість працівників в освітній організації; кількість учнів в освітній організації; статус освітньої організації в освітній системі; статус інноваційності освітньої організації в освітній системі.

Важливість організаційного розвитку освітніх організацій, який передбачає, насамперед, постановку перед ними нових, інноваційних завдань, що відповідають соціально-економічним змінам, які відбуваються в суспільстві, прогнозування інноваційних змін та створення відповідних організаційно-психологічних умов для їх упровадження, підкреслює у своїх роботах Л. Карамушка [7].

Далі проаналізуємо психологічну характеристику організації, як розвиток педагогічного колективу освітньої організації, котрий реалізується в проявах підготовленості до діяльності (міра готовності колективу до рішення поставленої задачі), організованості (чіткий розподіл ролей і статусів у колективі, наявність формальної і неформальної структури), активності (здатність колективу здійснювати суспільно значиму діяльність і виражає міру реалізації фізичного та інтелектуального потенціалу iï членів), згуртованості (стійкість і єдність міжособистісних взаємовідносин і взаємодій, забезпечення стабільності і спадкоємності діяльності колективу), інтегративності (узгодженість внутрішньо групових процесів), референтності (членство в колективі $є$ для людей найбільш цінним i значимим) педагогічного колективу.

У попередніх наших дослідженнях [10] окреслено дієвість розвитку компонентів управлінської діяльності у контексті формування взаємостосунків менеджерів і педагогічного колективу, а саме таких складових як: авторитет менеджерів освіти та уміння підтримувати у вчителів потяг до розвитку учнів; уміння планувати свою діяльність, уміння приймати рішення; здатність контролювати оцінювання діяльності учнів; розвиток інноваційного потенціалу; комунікативний потенціал; уміння використовувати владу.

На думку І. Чубової [16], ефективне управління освітньою організацією передбачає ство- рення здорової творчої атмосфери в колективі 3 високою результативністю праці і знаходиться в прямій залежності від того, який стиль управління вибрав менеджер освіти.

Отже, слід підкреслити, що більшість дослідників стилів управління, зокрема освітніх організацій, акцентують увагу на тому, що психологічні характеристики освітньої організації мають важливе значення для розвитку інноваційних стилів управління.

Другу групу утворили організаційно-психологічні характеристики, які зумовлені особливостями діяльності та поведінки менеджерів освітніх організацій, та пов'язані з психологічними, організаційно-функціональними й соціально-демографічними характеристиками менеджерів освіти.

Проаналізуємо психологічні характеристики менеджерів освітніх організацій, а саме: а) особистісні характеристики менеджерів (екстраверсія - соціальна адаптивність, соціальна активність, самовпевненість та міжособистісна залученість; прив'язаність - дружелюбність та конформність; самоконтроль - прагнення досягати успіхів, зокрема в педагогічній діяльності, а також надійність, праця, примус чи напруженість, скованість та самоконтроль; емоційна стійкість - регулювання, узгодження чи пристосування та афект; експресивність - інтелект, культура та самостійність, незалежність, неуперередженість); б) здатність менеджерів до саморозвитку; в) креативність менеджерів (креативний потенціал; креативний підхід до розв'язання проблеми).

До організаційно-професійних характеристик менеджерів освіти віднесено: посада в освітній організації; рівень освіти; тип освіти; стаж діяльності; кваліфікаційна категорія; педагогічне звання; відзнаки.

Соціально-демографічні характеристики менеджерів освіти зумовлені статтю менеджерів освітніх організацій; віком менеджерів освітніх організацій; сімейним станом менеджерів освітніх організацій; наявністю дітей.

Особистісні характеристики менеджерів освітніх організацій впливають на розвиток інноваційних стилів управління так, як розкривають психологічну індивідуальну характеристику менеджерів освіти, адже відкритість новому досвіду $є$ інформативним показником для прогнозування креативних досягнень.

Можна вважати, що залежно від того, 3 якою силою менеджер освіти виражає свої почуття, переживання, емоції, з такою ж силою буде породжуватися широке розмаїття нових ідей, i тим вищим буде рівень розвитку інноваційних стилів управління у таких менеджерів освітніх організацій.

На думку О. Бондарчук [2], розвиток освітньої організації можливий за умови орієнтації мене- 
джерів освіти на особистісний розвиток. Сприйнятливий до нового менеджер освіти постійно стежить за передовим досвідом у своїй сфері діяльності, намагається впровадити його з урахуванням освітніх потреб населення, суспільства. Він системно і наполегливо займається самоосвітою, розвиває власні ідеї у процесі управлінської діяльності. Вбачаючи перспективи творчого розвитку, такий менеджер освіти прогнозує й аналізує свою діяльність, ефективно взаємодіє 3 батьками вихованців, колегами, науковими установами тощо.

Створення в освітніх організаціях організаційно-психологічних умов, може сприяти підвищенню рівня саморозвитку менеджерів освітніх організацій. Мова йде про актуалізацію у менеджерів інтересу до роботи (зокрема, на основі використання позитивних прикладів колег щодо нововведень в освітніх закладах та їх позитивних результатів), організація різних сучасних форм підвищення кваліфікації, у тому числі і дистанційних, впровадження креативного підходу у вирішенні управлінських завдань, партнерських норм взаємодії $з$ колегами (створення команд для вирішення різних освітніх завдань, надання підтримки один одному та ін.).

На значущість управлінського компонента звертала у своєму дослідженні В. Сич [15], зазначаючи, що, коли менеджер сприяє розвитку креативного потенціалу працівників, створюючи певне інноваційне середовища, то формується компонент педагогічної взаємодії, який реалізується через обмін досвідом і командну роботу.

Для досягнення якісних результатів управління освітньою організацією повинно базуватися на творчому підході, узагальненні кращого досвіду, упровадженні інновацій.

Потужним фактором розвитку особистості, що визначає її готовність змінюватися, відмовлятися від стереотипних способів поведінки та мислення $є$ креативний потенціал. Креативний потенціал менеджера в освітній організації забезпечує здатність до конструктивного, нестандартного мислення та поведінки, а також усвідомлення i розвиток свого професійного досвіду, який допоможе управлінцю більш ефективно знаходити оптимальні рішення організаційних, виробничих, управлінських проблем.

Отже, на основі аналізу літератури, можна говорити про те, що організаційно-психологічні характеристики менеджерів освітніх організацій (особистісні характеристики, здатність до саморозвитку, креативний потенціал) «спонукають» їх до розвитку інноваційних стилів управління, $\mathrm{i}$, в той же час, організаційно-психологічні харак- теристики менеджерів освіти можуть виступати одними із суттєвих характеристик розвитку інноваційних стилів управління. Тому вивчення організаційно-психологічні характеристики менеджерів освіти у контексті розвитку інноваційних стилів управління є одним з актуальних і практично спрямованих напрямів досліджень у сфері організаційної та економічної психології.

Далі проаналізуємо третю групу організаційно-психологічних характеристик, які зумовлені особливостями взаємодії менеджерів з освітніми організаціями (задоволеність роботою, показники суб'єктивного благополуччя, відданість організаціі).

А. Бейкер [19] підкреслював зв'язок задоволеності роботою 3 продуктивністю і ефективністю діяльності, а також з організаційною лояльністю. Захоплені роботою менеджери освіти мають високу особисту ефективність, вірять, що здатні впоратися з будь-якими робочими проблемами, оптимістичні щодо своєї роботи і життя, вважають себе здатними задовольнити свої потреби в рамках виконуваних ними організаційних ролей.

На думку Л. Карамушки [6], впровадження вектору розвитку здорової освітньої організації зможе «задати вектор» діяльності освітньої організації в цілому. Оскільки, вміння створювати позитивне соціальне оточення та постійно ефективно взаємодіяти з ним, $є$ важливим психологічний ресурсом організації життєдіяльності менеджера освіти.

Прагнення менеджерів освіти брати участь у житті організації, готовність нести відповідальність за їі інтереси та цілі, запроваджуючи інноваційні підходи до розвитку організації і $€$ результатом упровадження інноваційних стилів управління.

Висновки. Отже, з урахуванням теоретичних підходів до аналізу інноваційних стилів управління менеджерів освітніх організацій, зокрема вивчення організаційно-психологічних характеристик розвитку інноваційних стилів управління, сприятимуть розвитку інноваційних стилів управління менеджерів освіти та їхній ефективній діяльності.

Урахування викладених вище підходів до аналізу інноваційних стилів управління менеджерів освіти можуть бути покладені в основу як емпіричних досліджень, спрямованих на вивчення організаційно-психологічних характеристик розвитку й особливостей діяльності освітніх організацій, так і в основу тренінгових програм для психологічної підготовки менеджерів освітніх організацій. 


\section{ЛITЕРАТУРА}

1. Андрушків Б.М., Кузьмін О.С. Основи менеджменту. Львів : Світ, 1995. 296 с.

2. Бондарчук О.І. Проблема впливу організаційного розвитку на особистісний розвиток персоналу організацій // Актуальні проблеми психології. Том 1 : Організаційна психологія. Економічна психологія. Соціальна психологія : зб. наукових праць Інституту психології ім. Г. С. Костюка АПН України / за ред. С. Д. Максименка, Л. М. Карамушки. Київ : А.С.К., 2010. Част. 28. - С. 172-177.

3. Боумен К. Основы стратегического менеджменту. Москва : ЮНИТИ, 1997. 175 с.

4. Журавлев А.Л. Стиль и эффективность руководства в производственном коллективе : дисс. ... канд. псих. наук. Москва : Изд-во ИПАН СССР, 1976. 326 с.

5. Карамушка Л.М. Технологічний підхід в діяльності організаційних психологів: сутність та основні форми реалізації // Педагогічна і психологічна наука в Україні : зб. наук. праць; у 5 т. Т. 2 : Психологія, вікова фізіологія та дефектологія. Київ : Пед. думка, 2012. С. 182-194.

6. Карамушка Л.М., Дзюба Т.М. Феномен «здоров'я» як актуальний напрям досліджень в організаційній психології // Організаційна психологія. Економічна психологія. 2019. № 1(16). С. 22-33.

7. Карамушка Л.М. Психологія діяльності організацій в умовах соціально-економічних змін (на матеріалі освітніх організацій) : монографія. Київ : Пед. думка, 2008. 192 с.

8. Карамушка Л.М. Психологія управління : навч. посібник для вузів. Київ : Міленум, 2003. 421 с.

9. Клочко А.О. Типи менеджерів освітніх організацій за їхнім ставлення до змін: зв'язок із характеристиками організації // Організаційна психологія. Економічна психологія : науковий журнал. 2020. № 4 (21). С. 73-81.

10. Клочко А.О. Традиційні та інноваційні стилі управління менеджерів освітніх організацій (у контексті формування взаємостосунків менеджерів і педагогічного колективу) // Організаційна психологія. Економічна психологія : науковий журнал. 2018. № 4 (15). С. 59-70.

11. Коломінський Н.Л. Психологія менеджменту в освіті (соціально-психологічний аспект) : монографія. Київ : МАУП, 2000. 286 с.

12. Лозниця В.С. Психологія і педагогіка : навч. посіб. для самостійного вивчення дисципліни. Київ : ЕксОб, 2000. 304 с.

13. Мескон М., Альберт М., Хедоури Ф. Основы менеджмента. Москва : Дело, 2004. 800 с.

14. Орбан-Лембрик Л.Е. Психологія управління : навч. посібник. Івано-Франківськ: Плай, 2001. 695 с.

15. Сич В.М. Сутність креативного потенціалу та його роль у психологічному забезпеченні управління закладами освіти // Проблеми сучасної психології : зб. наук. праць КПНУ імені Івана Огієнка, Інституту психології імені Г. С. Костюка НАПН України. Київ : 2012. Вип. 15. С. 586-596.

16. Чубова I.І. Особистісна диференціація індивідуальних стилів управлінської діяльності керівників загальноосвітніх навчальних закладів : автореф. дис. на здобуття наук. ступеня канд. псих. наук : спец. 19.00.05 «Соціальна психологія; психологія соціальної роботи». Сєвєродонецьк, 2017. 256 с.

17. Шакуров Р.Х. Социально-психологические основы управления : руководитель и педагогический коллектив. Москва : Просвещение, 1990. 208 с.

18. Шредер Г.А. Руководить сообразно ситуации. Москва : АО «Интерэксперт», 1994. 160 с.

19. Bakker A., Leiter M. Where to go from here: Integration and future research on work engagement. In A. Bakker, M. Leiter (eds.), Work engagement: A handbook of essential theory and research. Psychology Press. 2010. P. 181-196.

\section{REFERENCES}

1. Andrushkiv, B.M., \& Kuzmin, O.Ie. (1995) Osnovy menedzhmentu [Fundamentals of management]. Lviv : Svit [in Ukrainian].

2. Bondarchuk, O.I. (2010) Problema vplyvu orhanizatsiinoho rozvytku na osobystisnyi rozvytok personalu orhanizatsii [The problem of the influence of organizational development on the personal development of personnel of organizations] // Aktualni problemy psykholohii. Tom 1: Orhanizatsiina psykholohiia. Ekonomichna psykholohiia. Sotsialna psykholohiia : zb. naukovykh prats Instytutu psykholohii im. H. S. Kostiuka APN Ukrainy / za red. S. D. Maksymenka, L. M. Karamushky. Kyiv : A.S.K., Chast. 28 [in Ukrainian].

3. Boumen, K. (1997) Osnovbl stratehycheskoho menedzhmentu [Fundamentals of strategic management]. Moskva : YuNYTY [in Russian].

4. Zhuravlev, A.L. (1976) Styly эffektyvnost rukovodstva v proyzvodstvennom kollektyve [Style and efficiency of management in the production team]. Moskva : Yzd-vo YPAN SSSR [in Russian].

5. Karamushka, L.M. (2012) Tekhnolohichnyi pidkhid v diialnosti orhanizatsiinykh psykholohiv: sutnist ta osnovni formy realizatsii [Technological approach in the activities of organizational psychologists: the 
essence and basic forms of implementation] // Pedahohichna i psykholohichna nauka v Ukraini : zb. nauk. prats; $u 5$ t. T. 2 : Psykholohiia, vikova fiziolohiia ta defektolohiia. Kyiv : Ped. dumka [in Ukrainian].

6. Karamushka, L.M., \& Dziuba, T.M. (2019) Fenomen «zdorovia» yak aktualnyi napriam doslidzhen v orhanizatsiinii psykholohii [The phenomenon of "health" as a relevant area of research in organizational psychology] // Orhanizatsiina psykholohiia. Ekonomichna psykholohiia. 1(16) [in Ukrainian].

7. Karamushka, L.M. (2008) Psykholohiia diialnosti orhanizatsii v umovakh sotsialno-ekonomichnykh zmin (na materiali osvitnikh orhanizatsii) [Psychology of activity of the organization in the conditions of social and economic changes (an example of educational organizations)]. Kyiv: Pedahohichna dumka [in Ukrainian].

8. Karamushka, L.M. (2003) Psykholohiia upravlinnia [Management psychology]. Kyiv: Milenum [in Ukrainian].

9. Klochko, A.O. (2020) Typy menedzheriv osvitnikh orhanizatsii za yikhnim stavlennia do zmin: zviazok iz kharakterystykamy orhanizatsii [Types of managers of educational organizations according to their attitude to change: connection with the characteristics of the organization] // Orhanizatsiina psykholohiia. Ekonomichna psykholohiia : naukovyi zhurnal. 4 (21) [in Ukrainian].

10. Klochko, A.O. (2018) Tradytsiini ta innovatsiini styli upravlinnia menedzheriv osvitnikh orhanizatsii (u konteksti formuvannia vzaiemostosunkiv menedzheriv i pedahohichnoho kolektyvu) [Traditional and innovative management styles of managers of educational organizations (in the context of forming the relationship between managers and teaching staff)] // Orhanizatsiina psykholohiia. Ekonomichna psykholohiia : naukovyi zhurnal. 4 (15) [in Ukrainian].

11. Kolominskyi, N.L. (2000) Psykholohiia menedzhmentu v osviti (sotsialno-psykholohichnyi aspekt) [Psychology of management in education (socio-psychological aspect)]. Kyiv : MAUP [in Ukrainian].

12. Loznytsia, V.S. (2000) Psykholohiia i pedahohika [Psychology and pedagogy]. Kyiv : EksOb[in Ukrainian].

13. Meskon, M., Albert, M., \& Khedoury, F. (2004) Osnovbl menedzhmenta [Fundamentals of Management]. Moskva : Delo [in Russian].

14. Orban-Lembryk, L.E. (2003) Psykholohiia upravlinnia [Management psychology]. Kyiv: Akademvydav [in Ukrainian].

15. Sych, V.M. (2012) Cutnist kreatyvnoho potentsialu ta yoho rol u psykholohichnomu zabezpechenni upravlinnia zakladamy osvity [The essence of creative potential and its role in the psychological management of educational institutions] // Problemy suchasnoi psykholohii : zb. nauk. prats KPNU imeni Ivana Ohiienka, Instytutu psykholohii imeni H. S. Kostiuka NAPN Ukrainy. Kyiv. Vyp. 15 [in Ukrainian].

16. Chubova, I.I. (2017) Osobystisna dyferentsiatsiia indyvidualnykh styliv upravlinskoi diialnosti kerivnykiv zahalnoosvitnikh navchalnykh zakladiv [Personal differentiation of individual management styles of heads of secondary schools]. Sievierodonetsk [in Ukrainian].

17. Shakurov, R.Kh. (1990) Sotsyalno-psykholohycheskye osnovb upravlenyia : rukovodytel y pedahohycheskyi kollektyv [Socio-psychological bases of management: the head and pedagogical collective]. Moskva : Prosveshchenye [in Russian].

18. Shreder, H.A. (1994) Rukovodyt soobrazno sytuatsyy [Lead according to the situation]. Moskva : AO «Ynterekspert» [in Russian].

19. Bakker, A., \& Leiter, M. (2010) Where to go from here: Integration and future research on work engagement. Work engagement: A handbook of essential theory and research. Psychology Press. 2010. P. 181-196. 